\title{
Microbial plankton response to resource limitation: insights from the community structure and seston stoichiometry in Florida Bay, USA
}

\author{
Peter J. Lavrentyev ${ }^{1, * * *}$, Harvey A. Bootsma ${ }^{1, * * *}$, Thomas H. Johengen ${ }^{1}$, \\ Joann F. Cavaletto ${ }^{2}$, Wayne S. Gardner ${ }^{2, * *}$ \\ ${ }^{1}$ University of Michigan, Cooperative Institute for Limnology and Ecosystem Research, 2200 Bonisteel Boulevard, \\ Ann Arbor, Michigan 48109, USA \\ ${ }^{2}$ National Oceanic and Atmospheric Administration, Great Lakes Environmental Research Laboratory, \\ 2205 Commonwealth Boulevard, Ann Arbor, Michigan 48105, USA
}

\begin{abstract}
Concentrations of dissolved and particulate nutrients, chlorophyll, and microorganisms $(0.01$ to $200 \mu \mathrm{m})$ were simultaneous]y measured during a $1 \mathrm{~d}$ survey of 12 stations in Florida Bay, USA, to characterize the microbial plankton community with respect to resource limitation. Three distinct types of trophic conditions, reflected in seston elemental stoichiometry and community structure, were identified within the bay. The first type, characteristic of the isolated eastern region, had low nutrient concentrations, imbalanced stoichiometry, and small microbial biomass with a large proportion of bacteria. The microbial community in this region was characterized by weak relationships between microzooplankton and phytoplankton and the predominance of mixotrophic taxa and the autotrophic ciliate Mesodinium rubrum. The second type, found in the north-central region influenced by Taylor Slough inflow, had elevated nutrient concentrations, elemental stoichiometry skewed toward $\mathrm{N}$, and high turbidity. Under these conditions, the picocyanobacterium Synechococcus formed a dense bloom and coincided with an abundant, multi-step microbial food web. Finally, at the boundary with the Gulf of Mexico, low concentrations of nutrients were balanced at approximately the Redfield ratio and supported nanophytoplankton that were tightly correlated with microzooplankton. These data are consistent with the notion of P limitation in Florida Bay but also demonstrate that Si, light, and $\mathrm{N}$ may be colimiting to phytoplankton in the eastern, north-central, and western boundary regions, respectively. Our findings suggest that multiple resource gradients, in conjunction with microbial food web processes, are important factors determining the plankton community structure in Florida Bay and should be considered in studies on ecological disturbances.
\end{abstract}

KEY WORDS: Subtropical lagoon . Nutrient limitation - Seston stoichiometry Phytoplankton Microbial food web

\section{INTRODUCTION}

Abiotic resources (i.e. nutrients and light) are major factors shaping the structure of planktonic communities (Kilham \& Hecky 1988, Sommer 1993). Measuring

\footnotetext{
-E-mail: peterl@utmsi.utmsi.utexas.edu

Present addresses:

- University of Texas at Austin, Marine Science Institute, 750 Channelview Drive, Port Aransas, Texas 78373, USA

-..SADC / GEF Lake Malawi / Nyasa Biodiversity Conservation Project, PO Box 311, Salima, Malawi
}

dissolved nutrient concentrations and ratios provides some insights about nutrient availability and growth conditions for aquatic organisms, whereas the elemental composition of particles contains integrated information about nutrient limitation and trophodynamics of planktonic organisms (Hecky \& Kilham 1988, Elser \& Hasset 1994). However, some organisms are able to sustain growth at very low concentrations of dissolved nutrients (Goldman \& Gilbert 1983), and resuspension of sediments in shallow waters and inputs of allochthonous solids can hinder interpreta- 
tion of results in seston stoichiometry studies (Hecky et al. 1993).

It is increasingly recognized that the microbial food web plays a fundamental role in the pelagic environment (Sherr et al 1988, Legendre \& Rassoulzdegan 1995). Planktonic microorganisms have short turnover times, typically ranging from a few days to a few hours (Fahnenstiel et al. 1995, Montagnes 1995) and highly specific resource requirements (Haigh et al. 1992, Sommer 1993). One may expect, therefore, that they will give rapid and distinct responses to resource conditions. In turn, the structure of microbial communities can have significant effects on biogeochemical cycles of nutrients (Suzuki et al. 1996, Lavrentyev et al. 1997). Nevertheless, the entire microbial plankton $(\leq 200 \mu \mathrm{m})$, representing a wide array of autotrophic, heterotrophic, and mixotrophic organisms, have been rarely examined together, particularly with respect to resource conditions (Caron et al. 1995).

A complication in plankton-nutrient studies is the interference from physical factors. In coastal systems, physical forcing often has profound effects on pelagic resource-driven processes (Haigh \& Taylor 1991, Nielsen \& Kiørboe 1991). Under these conditions, approaches in plankton-nutrient studies are often limited to the use of isolated volumes even though the planktonic community structure and nutrient fluxes can be significantly altered by containment, especially in long incubations. Florida Bay, USA, naturally presents an alternative to using containers or mesocosms, because it encompasses regionally diverse environments, where a 'snap-shot' of plankton-nutrient interactions can be observed without the containment of organisms.

Florida Bay is a large $\left(1500 \mathrm{~km}^{2}\right)$, shallow (0 to $4 \mathrm{~m}$ ) inner-shelf lagoon, located at the southern tip of the Florida Peninsula between the Everglades wetland and the Florida Keys chain of islands. A network of partially submerged mud banks and multiple islands (keys) causes extraordinary damping of diurnal and semidiurnal tides in the bay (Wang et al. 1994). The low tidal exchange between the central and eastern parts of Florida Bay and adjacent waters of the Gulf of Mexico and Florida Straits and reduced circulation within the bay create partial isolation of water masses in subregions (Wang et al. 1994). This compartmentalization, in turn, results in strong gradients in salinity and water clarity (Phlips et al. 1995), as well as in concentrations of macronutrients and chlorophyll (Fourqurean et al. 1993, Phlips \& Badylak 1996).

During the last several years, proliferation of algal blooms in Florida Bay has coincided with widespread die-offs of the dominant seagrass Thalassia testudinium (Boesch et al. 1993. Thayer et al. 1994) and the cascading disturbances that affect many commercially valuable species in this region (Butler et al. 1994).
Severe fluctuations in salinity, reaching $60 \%$ in the mid bay, due to the reduction of freshwater inflow from the Everglades (Fourqurean et al. 1992, Montague \& Ley 1993) and eutrophication via general non-point and point sources (LaPointe \& Clark 1992) have been alternatively suggested as major factors causing the disturbances, but the exact mechanistic reasons for these changes remain unclear.

In this study, we hypothesized that resource conditions were the major factor controlling the distributions of microbial plankton in the partially isolated areas of Florida Bay and that these conditions were, in turn, affected by microbial community structure in these regions. If this concept is valid, it could have major implications for further studies and management of the Florida Bay ecosystem. To address these issues, we examined the microbial plankton community and seston stoichiometry with respect to the concentrations and ratios of dissolved nutrients in different parts of Florida Bay and compared them to the shelf-influenced waters bordering the Gulf of Mexico.

\section{MATERIAL AND METHODS}

Sampling locations and field measurements. Samples were collected on February 22, 1995 at 12 stations throughout Florida Bay (Fig. 1). Temperature, pH, turbidity, and dissolved oxygen concentrations were measured with a Hydrolab Surveyor II. Salinity was measured with a Leica temperature-compensated refractometer. Water samples were collected from the subsurface layer $(0.5 \mathrm{~m})$ by forcing clean polycarbonate carboys underwater with the mouth pointing downward, leaving the spigot at the base of the carboy open for air release. Subsamples for chemical and microscopic analyses were simultaneously taken from the carboys, immediately preserved as described below, and then transported to the land-based laboratory in insulated coolers.

Chemical parameters. Dissolved nutrients: nitrates $\left(\mathrm{NO}_{3}{ }^{-}=\right.$nitrite plus nitrate), total dissolved nitrogen (TDN), total dissolved phosphorus (TDP), soluble reactive phosphorus (SRP), and soluble reactive silicon (SRSi) were determined using a Technicon II autoanalyzer (Davis \& Simmons 1979). Ammonium $\left(\mathrm{NH}_{4}{ }^{+}\right.$) was determined by high-performance liquid chromatography (Gardner \& St. John 1991). Dissolved inorganic nitrogen (DIN) was calculated as the sum of ammonium and nitrates. Suspended solids were collected onto pre-combusted and pre-weighed Whatman GF/F filters. Particulate carbon (PC) and particulate nitrogen (PN) were analyzed on a Perkin Elmer $2400 \mathrm{CHN}$ analyzer. Particulate phosphorus (PP) filters were digested in persulfate (Menzel \& Corwin 1965) followed by standard SRP analysis. 
Fig. 1. Map of the study area showing sampling locations (upper boldface numbers), salinity (\%o; lower numbers), and regions within Florida Bay, USA: E, eastern; NC, north-central; $B$, boundary (see explanation in 'Results')

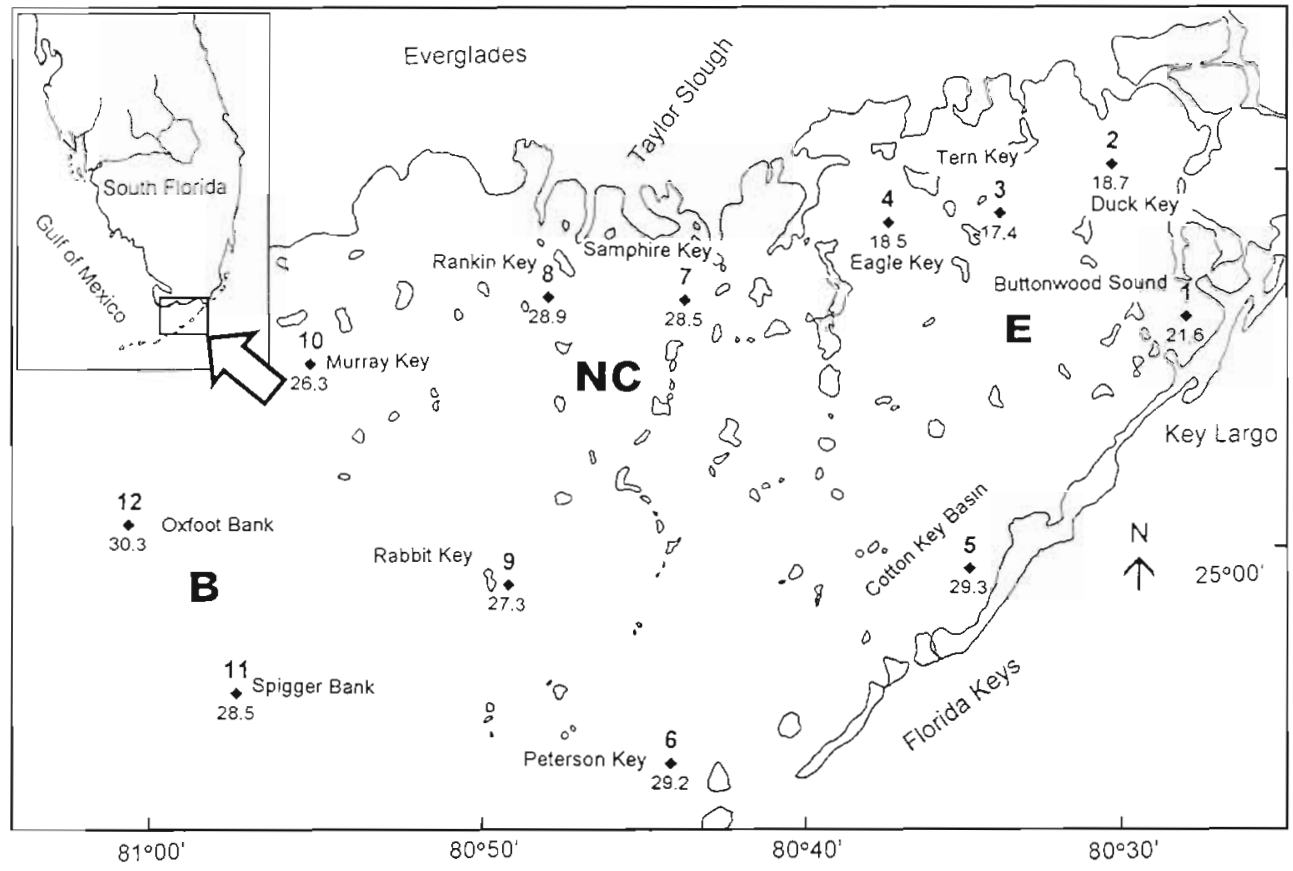

Chlorophyll samples were filtered onto $47 \mathrm{~mm}$ Whatman GF/F filters and stored frozen in amber vials. Chlorophyll was extracted by grinding filters in icecold $90 \%$ acetone. After grinding, the extracts were held at near $0^{\circ} \mathrm{C}$ for $24 \mathrm{~h}$, then the samples were centrifuged and chlorophyll concentrations were determined with a Turner Designs 10 005R fluorometer (Strickland \& Parsons 1972). The measurements were corrected for phaeophytin.

Microbial plankton. Picoplankton-sized $(<2 \mu \mathrm{m})$ cyanobacteria and eukaryotes were counted on $0.2 \mu \mathrm{m}$ membrane filters under a Leitz epifluorescence microscope equipped with a green excitation filter set from preparation made immediately after sampling and stored frozen at $-20^{\circ} \mathrm{C}$ (Fahnenstiel et al. 1991). Viruses and virus-like particles were concentrated from $0.2 \mu \mathrm{m}$ pre-filtered samples onto $0.01 \mu \mathrm{m}$ black PCTE Poretics filters and counted via fluorescent microscopy (magnification 1000x) using YO-Pro stain (Hennes \& Suttle 1994). Prior to staining, the particles were rinsed with several changes of $0.01 \mu \mathrm{m}$ prefiltered deionized-distilled water to remove preservative. Bacteria preserved with $1 \%$ (final concentration) formaldehyde were counted using DAPI stain (Porter $\&$ Feig 1980) to reduce interference from detrital materials.

Nanoplankton preserved with $1 \%$ (final concentration) formaldehyde were counted using the dualstaining (FITC/DAPI) procedure (Sherr et al. 1993) on $0.8 \mu \mathrm{m}$ filters. The presence or absence of chlorophyll autofluorescence distinguished photosynthetic and heterotrophic flagellates and dinoflagellates from each other. Microplankton were counted in settling chambers using a Wild phase contrast inverted microscope (magnification 125 to $625 \times$ ) after fixation of whole water samples with $6 \%$ (final concentration) freshly prepared acid Lugol's iodine. Additionally, loricate ciliates, large dinoflagellates, and colonial protists, which were not always present in sufficient numbers to be counted in the whole water, were counted from samples pre-concentrated by gentle gravity reverse filtration using a $20 \mu \mathrm{m}$ net. Protozoa and phytoplankton were identified to the genus level. Taxonomic composition of protozoa was determined using silver staining (Montagnes \& Lynn 1987, Skibbe 1994) and in vivo observations. Crustaceans were not included in this study because our methods of collection were not adequate for precise sampling of zooplankton, which were too rare to be accurately counted in our small samples.

Biomass of phytoplankton and protozoa was estimated from linear dimensions of individual cells by approximating geometric solids and converting their biovolume to carbon according to Montagnes et al. (1994) and Putt \& Stoecker (1989). Bacterial biomass was determined with allometric equations (Norland 1993) and then an average was calculated for each size category. The microbial plankton in the bay were grouped in the following conventional categories based on their size and taxonomic position: viruses and viruslike particles, bacteria, cyanobacteria, photosynthetic and heterotrophic nanoflagellates and dinoflagellates, i.e. those with and without visible chloroplasts, nanoplanktonic $(<20 \mu \mathrm{m})$ and microplanktonic $(>20 \mu \mathrm{m})$ diatoms, aloricate oligotrichous ciliates (including 
heterotrophic and mixotrophic oligo- and choreotrichs), tintinnids, and prorodontid ciliates. The virtually autotrophic ciliate Mesodinium rubrum (= Myrionecta rubra) was allocated as a separate group.

Statistics. Statistical relationships between selected variables were described using Pearson correlation and principal component analyses (PCA). To advance the interpretation of the factors in the PCA, they were rotated using an orthogonal rotation method (VARIMAX) that minimizes the number of variables that have high loadings on each factor (SYSTAT 1992). The factor scores were calculated at each site for the first 2 principal components.

\section{RESULTS}

\section{Field measurements}

Temperature, $\mathrm{pH}$, and dissolved oxygen concentrations varied from 19.1 to $23.3^{\circ} \mathrm{C}, 7.85$ to 8.24 , and 7.23 to $8.44 \mathrm{mg} \mathrm{O}_{2} \mathrm{l}^{-1}$, respectively. Turbidity was 9.9 (nephelometer turbidity units, NTU) \pm 4.1 (standard deviation, SD), $8.9 \pm 1.6,27.2 \pm 13.6$, and $55.5 \pm 17.7$ at Rabbit Key, Duck Key, Murray Key, and Rankin Key (Fig. 1), respectively. Salinity varied from 17.4 to $30.3 \%$ across the bay, increasing in a westerly direction. Wind was easterly and ranged from 6 to $7.5 \mathrm{~m} \mathrm{~s}^{-1}$

\section{Regional division}

Concentrations and ratios of dissolved and particulate nutrients and biotic parameters were used as variables in the PCA. The first 2 components of the rotated solution explained ca $71 \%$ of the total variance, describing 3 major eco-regions within Florida Bay (Fig. 2). The first factor described increased concentrations of dissolved and particulate nutrients and chlorophyll as well as biomass of bloom-forming algae and the associated microbial plankton, thus differentiating the northcentral region (NC), including Samphire Key (Stn 7) and Rankin Key (Stn 8), from the rest of the stations.

The second factor reflected a decrease in the degree of $\mathrm{P}$ limitation along the east-west transect and the associated changes in the microbial community structure. The eastern region (E), including Buttonwood Sound (Stn 1), and Duck (Stn 2), Tern (Stn 3), and Eagle Keys (Stm 4) and the Gulf boundary region (B), represented by Spigger (Stn 11) and Oxfoot Banks (Stn 12), were the extremes in this transect. Cotton Key Basin (Stn 5) and Peterson Key (Stn 6), both located near Florida Keys, appeared to be transitional with respect to the described factors as well as the westerly located Rabbit and Murray Keys (Stns 9 and 10). This
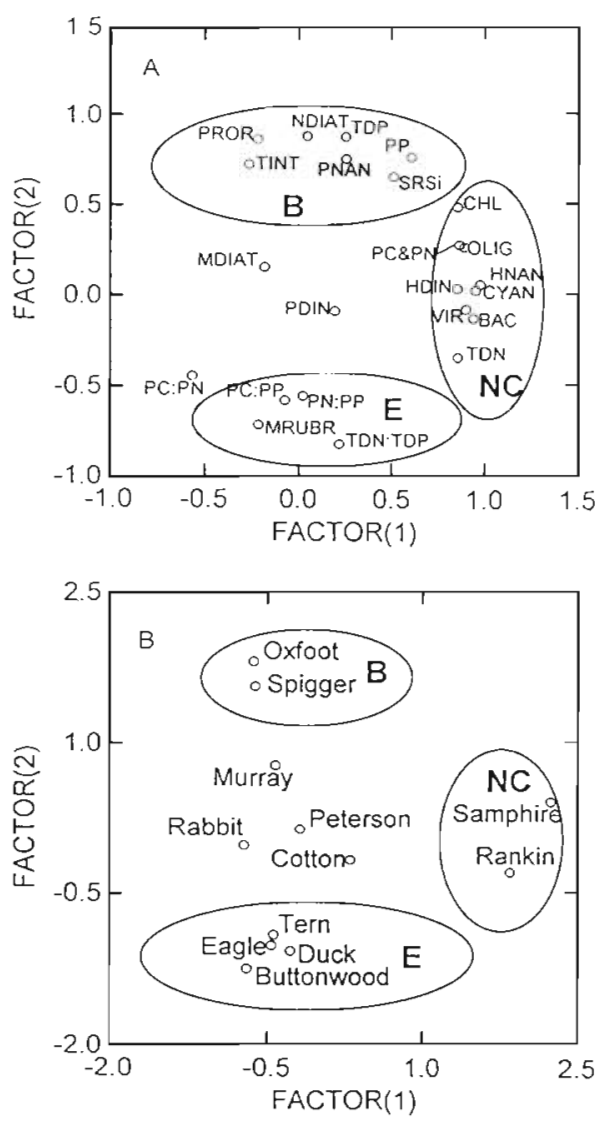

Fig. 2. (A) Factor loadings and (B) factor scores in the principal component analysis. Phytoplankton: CYAN, cyanobacteria; PDIN, photosynthetic dinoflagellates; PNAN, photosynthetic nanoflagellates; NDIAT, nano-diatoms; MDIAT, micro-diatoms. Protozoa: MRUBR, Mesodinium rubrum, HNAN, heterotrophic nanoflagellates; HDIN, heterotrophic dinoflagellates; OLIG, oligotrich ciliates; TINT, tintinnid ciliates; PROR, prorodontid ciliates. BAC: bacteria; CHL: chlorophyl, VIR: viruses. Chemical abbreviations explained in 'Materials and methods'. Regions ( $B, N C, E)$ as in Fig. 1

regional division was used in the following description of nutrient conditions and the plankton community structure in Florida Bay.

\section{Dissolved nutrients}

The eastern region had low concentrations of dissolved nutrients and the highest TDN:TDP ratios, particularly in the easternmost locations, Buttonwood Sound and Duck Key (Table 1). In this region, SRP (here and throughout the text, the chemical abbreviations refer to concentrations) was below the detection limit (ca $0.03 \mu \mathrm{M}$ ) as it was in most other studied locations. The lowest SRSi was also observed in the eastern region and TDP was 3 times lower than in the northcentral and boundary regions. 
Table 1. Dissolved nutrients concentrations $(\mu \mathrm{M})$, and molar ratios in Florida Bay. Regions as in Fig. 1; -: transitional stations. TDN: total dissolved nitrogen; TDP: total dissolved phosphorus; SRSi: soluble reactive silicon; DIN: dissolved inorganic nitrogen; DL: concentration below detection limit. NE: not estimated

\begin{tabular}{|c|c|c|c|c|c|c|c|c|c|c|}
\hline No. & Station & Region & $\mathrm{NO}_{3}^{-}$ & $\mathrm{NH}_{4}^{+}$ & TDN & TDP & SRSi & TDN:TDP & $\mathrm{NH}_{4}{ }^{+}: \mathrm{NO}_{3}{ }^{-}$ & SRSi:DIN \\
\hline 1 & Buttonwood Sound & $E$ & 0.34 & 0.77 & 28.61 & 0.06 & 2.80 & 443.9 & 2.3 & 2.5 \\
\hline 2 & Duck Key & $E$ & 1.53 & 0.41 & 21.61 & 0.05 & 3.59 & 414.8 & 0.3 & 1.85 \\
\hline 3 & Tern Key & $E$ & DL & 0.67 & 27.00 & 0.08 & 4.18 & 353.5 & NE & 6.2 \\
\hline 4 & Eagle Key & $E$ & DL & 1.17 & 15.23 & 0.06 & 2.40 & 235.8 & $\mathrm{NE}$ & 2.0 \\
\hline 5 & Cotton Key Basin & - & 1.46 & 2.69 & 18.25 & 0.11 & 4.57 & 170.5 & 1.8 & 1.1 \\
\hline 6 & Peterson Key & - & 0.90 & 2.96 & 17.32 & 0.18 & 4.57 & 96.1 & 3.3 & 1.2 \\
\hline 7 & Samphire Key & $\mathrm{NC}$ & 2.34 & 26.13 & 52.05 & 0.19 & 1.4 .03 & 270.6 & 11.2 & 0.5 \\
\hline 8 & Rankin Key & $\mathrm{NC}$ & 0.76 & 7.65 & 42.91 & 0.16 & 16.39 & 265.1 & 10.1 & 1.9 \\
\hline 9 & Rabbit Key & - & DL & DL & 18.64 & 0.17 & 6.74 & 111.2 & NE & $\mathrm{NE}$ \\
\hline 10 & Murray Key & - & $\mathrm{DL}$ & 0.31 & 18.45 & 0.19 & 17.38 & 95.7 & NE & 56.0 \\
\hline 11 & Spigger Bank & W & 0.18 & 0.46 & 7.35 & 0.19 & 13.24 & 37.9 & 2.6 & 20.7 \\
\hline 12 & Oxfoot Bank & W & 0.18 & 0.27 & 3.03 & 0.20 & 8.58 & 14.8 & 1.5 & 19.1 \\
\hline
\end{tabular}

The north-central region, had the highest concentrations of TDN and DIN. The predominant form of DIN, $\mathrm{NH}_{4}^{+}$, was 1 order of magnitude higher in this part of Florida Bay than at all other stations. The $\mathrm{NH}_{4}{ }^{+}: \mathrm{NO}_{3}{ }^{-}$ ratio exceeded 10:1. SRP was measurable $(0.05 \mu \mathrm{M})$ only at Samphire Key. Both north-central sites had elevated TDP and SRSi, as was characteristic of all sites located west of Cotton Key Basin, whereas the TDN: TDP ratios were close to those in the eastern region.

The boundary region between Florida Bay and the Gulf of Mexico had low concentrations of dissolved inorganic nutrients, except for SRSi. The TDP was similar to other sites in the western and mid sections of the bay, whereas both TDN and the TDN:TDP ratios were lower than in the other regions.

Transitional with respect to the above 3 regions, Petersen Key and Cotton Key Basin had measurable SRP $(0.04 \mu \mathrm{M})$, and the former site also had TDP comparable to those at north-central and western locations. The TDN:TDP ratios were at an intermediate level here as well as at the other 2 transitional sites, Murray Key and Rabbit Key. However, the latter sites had SRP below detection limit and the lowest DIN, whereas SRSi was high.

\section{Particulate nutrients and seston composition}

In the eastern region, $\mathrm{PC}, \mathrm{PN}$, and $\mathrm{PP}$ concentrations were comparatively low, whereas the PC:PP and PN:PP ratios were high (Table 2). The PC:PN ratio did not differ significantly between the regions. The lowest ratios of LIVE (the sum of microscopically determined biomass of different microorganisms, Table 3) to PC occurred in the eastern Cotton Key Basin and Tern Key. Algal contribution to PC (PHYT:PC) was 2 to 2.5 times lower in the eastern region than at western and north-central sites. Alternately, the maximum heterotrophic to photosynthetic biomass ratio (HET: PHOT) occurred within this region (Table 2).

Table 2. Particulate nutrients concentrations $(\mu \mathrm{M})$ and molar ratios, and seston composition in Florida Bay. PC: particulate carbon; PN: particulate nitrogen; PP: particulate phosphorus; LIVE: sum of microscopically determined biomasses of planktonic organisms (Table 3); PHYT: phytoplankton biomass; HET:PHOT: ratio of heterotrophic to photosynthetic components of the living carbon. Regions as in Fig. 1; -: transitional stations

\begin{tabular}{|c|c|c|c|c|c|c|c|c|c|c|c|}
\hline No. & Station & Region & $\mathrm{PC}$ & PN & $\mathrm{PP}$ & PC:PN & PC:PP & $P N: P P$ & LIVE:PC & PHYT:PC & HET:PHOT \\
\hline 1 & Buttonwood Sound & $\mathrm{E}$ & 18.6 & 1.6 & 0.065 & 11.3 & 286.8 & 25.3 & 0.33 & 13.50 & 0.82 \\
\hline 2 & Duck Key & $E$ & 24.0 & 2.4 & 0.066 & 9.8 & 363.3 & 37.0 & 0.36 & 12.30 & 0.90 \\
\hline 3 & Tern Key & $\mathrm{E}$ & 38.0 & 3.4 & 0.095 & 11.1 & 399.9 & 36.2 & 0.16 & 15.17 & 1.24 \\
\hline 4 & Eagle Key & $E$ & 21.2 & 1.85 & 0.017 & 11.4 & 1264.3 & 110.5 & 0.24 & 15.45 & 0.85 \\
\hline 5 & Cotton Key Basin & - & 99.9 & 11.2 & 0.164 & 8.9 & 609.5 & 68.3 & 0.17 & 5.43 & 0.37 \\
\hline 6 & Peterson Key & - & 52.2 & 5.4 & 0.161 & 9.6 & 324.2 & 33.9 & 0.21 & 11.54 & 0.54 \\
\hline 7 & Samphire Key & $\mathrm{NC}$ & 119.3 & 13.8 & 0.380 & 8.7 & 317.4 & 36.6 & 0.33 & 22.97 & 0.45 \\
\hline 8 & Rankin Key & $\mathrm{NC}$ & 94.2 & 9.75 & 0.255 & 9.7 & 369.4 & 38.2 & 0.37 & 25.59 & 0.42 \\
\hline 9 & Rabbit Key & - & 25.1 & 2.1 & 0.094 & 11.7 & 267.3 & 22.8 & 0.51 & 37.21 & 0.35 \\
\hline 10 & Murray Key & - & 46.0 & 5.2 & 0.275 & 8.8 & 167.3 & 19.1 & 0.39 & 33.29 & 0.18 \\
\hline 11 & Spigger Bank & $W$ & 52.6 & 5.1 & 0.256 & 10.3 & 205.1 & 19.9 & 0.34 & 26.36 & 0.40 \\
\hline 12 & Oxfoot Bank & W & 41.2 & 4.2 & 0.264 & 9.8 & 156.2 & 16.0 & 0.37 & 23.80 & 0.40 \\
\hline
\end{tabular}


Table 3. Concentrations of chlorophyll (CHL, $\mu \mathrm{g} \mathrm{l}^{-1}$ ) and viruses (VIR, particles $\left.10^{6} \mathrm{mnl}^{-1}\right)$; biomass of planktonic microorganisms ( $\mu \mathrm{g} \mathrm{C}^{-1}$ ): BAC, bacteria; NRUBR, Mesodinium rubrum; PHYT, phytoplankton; proportion of BAC $<1$ mm in biomass of BAC, and ratios between selected biotic variables in Florida Bay. PROT: Protozoan biomass (excluding $M$. rubrum); HNAN: heterotrophic nanoflagellates. Regions as in Fig. 1; -: transitional stations

\begin{tabular}{|c|c|c|c|c|c|c|c|c|c|c|c|c|}
\hline No. & Station & Region & CHL & VIR & MRUBR & $\mathrm{BAC}$ & $\begin{array}{c}\text { PHYT: } \\
\text { CHL }\end{array}$ & $\begin{array}{l}\text { MRUBR: } \\
\text { PHYT }\end{array}$ & PROT:PHYT & BAC:CHL & $\begin{array}{l}\% \mathrm{BAC} \\
<1 \mu \mathrm{m}\end{array}$ & $\begin{array}{c}\text { HNAN: } \\
\text { BAC }\end{array}$ \\
\hline 1 & Buttonwood Sound & $E$ & 0.18 & 7.2 & 6.2 & 20.1 & 200 & 0.18 & 0.38 & 114.9 & 16.7 & 0.16 \\
\hline 2 & Duck Key & $E$ & 020 & 84 & 995 & 30.3 & 2.2 .2 & 02.2 & 0.42 & 1.51 .5 & 44.2 & 0.065 \\
\hline 3 & Tern Key & $E$ & 0.17 & 5.4 & 7.5 & 32.6 & 143 & 0.30 & 0.30 & 197.6 & 24.5 & 0.07 \\
\hline 4 & Eagle Key & E & 0.12 & 5.8 & 4.2 & 19.9 & 250 & 0.14 & 0.30 & 165.8 & 22.7 & 0.07 \\
\hline 5 & Cotton Key Basin & - & 1.46 & 8.1 & 1.7 & 33.5 & 111 & 0.01 & 0.15 & 22.95 & 15.4 & 0.25 \\
\hline 6 & Peterson Key & - & 0.94 & 7.9 & 1.1 & 22.6 & 91 & 0.01 & 0.28 & 24.0 & 19.6 & 0.35 \\
\hline 7 & Samphire Key & $\mathrm{NC}$ & 4.16 & 30.3 & 1.9 & 78.9 & 80 & $<0.01$ & 0.21 & 19.0 & 15.7 & 0.25 \\
\hline 8 & Rankin Key & NC & 2.90 & 51.2 & 1.5 & 59.5 & 100 & $<0.01$ & 0.22 & 20.5 & 13.3 & 0.13 \\
\hline 9 & Rabbit Key & - & 0.80 & 4.7 & 1.0 & 31.6 & 143 & $<0.01$ & 0.07 & 39.5 & 38.3 & 0.31 \\
\hline 10 & Murray Key & - & 1.60 & 5.6 & 1.1 & 22.0 & 111 & $<0.01$ & 0.06 & 13.75 & 25.1 & 0.13 \\
\hline 11 & Spigger Bank & W & 1.71 & 4.8 & 1.25 & 12.3 & 91 & $<0.01$ & 0.32 & 7.2 & 9.6 & 0.21 \\
\hline 12 & Oxfoot Bank & W & 1.36 & 3.2 & 1.1 & 17.5 & 100 & $<0.01$ & 0.26 & 12.9 & 23.0 & 0.18 \\
\hline
\end{tabular}

The north-central region had the highest concentrations of particulate nutrients, but their ratios were similar to those in the eastern region.

In the boundary region, the PC:PP and PN:PP ratios approached the Redfield ratio with $\mathrm{PN}$ being close to or even exceeding TDN.

At the transitional sites, Cotton Key Basin and Peterson Key, the absolute concentrations of particulate nutrients were higher than in the eastern region, but the PC:PP and PN:PP ratios reflected the same nutrient misbalance, particularly at the former location. In contrast, Rabbit Key had PN:PP ratio close to those at the Gulf border and at Murray Key even though its PC, PN and PP were comparable to those in the eastern bay. Both the LIVE:PC and PHYT:PC ratios peaked at Rabbit Key that was closely followed by north-central sites and the 2 westernmost sites.

Results from the various sites were combined to examine statistical relationships. Here and throughout the text, all of the Pearson correlations shown are significant at the $95 \%$ probability level or higher. Particulate nutrient concentrations were positively related to those of dissolved nutrients $\left(\mathrm{PC}\right.$ to $\mathrm{NH}_{4}{ }^{+}, \mathrm{r}=0.76_{i} \mathrm{PN}$ to $\mathrm{NH}_{4}{ }^{+}, \mathrm{r}=0.78$; PP to TDP and SRSi, $\mathrm{r}=0.82$ and 0.86 , respectively). Tight correlations were also found between PC, PN, and PP and independently determined LIVE carbon ( $r=0.87,0.87$, and 0.69 , respectively). The HET:PHOT ratio was negatively related to TDP ( $\mathrm{r}=$ -0.81 ) and positively to the TDN:TDP ratio ( $r=0.73$ ). The PHYT:PC ratio correlated with the above nutrients in the opposite way.

\section{Chlorophyll and phytoplankton}

The eastern bay had the lowest phytoplankton biomass (Fig. 3) and chlorophyll concentrations (Table 3), the highest phytoplankton carbon-to-chlorophyll ratio (PHYT:CHL) and the lowest CHL:dissolved nutrient ratios of any of the regions (Fig. 4). Large diatoms and the dinoflagellates Prorocentrum and Pyrodinum were the predominant phytoplankton with a contribution from Ceratium and Gambrierdiscus. The photosynthetic ciliate Mesodinium rubrum (MRUBR) peaked in the eastern region contributing up to $30 \%$ of the phytoplankton biomass.

The north-central region had the highest concentrations of chlorophyll, maximum CHL:TDP and CHL:SRSi ratios, and the lowest PHYT:CHL ratio. The picoplankton-sized Synecochoccus contributed up to $77 \%$ of the phytoplankton biomass, forming a dense bloom, with a lesser contribution from photosynthetic
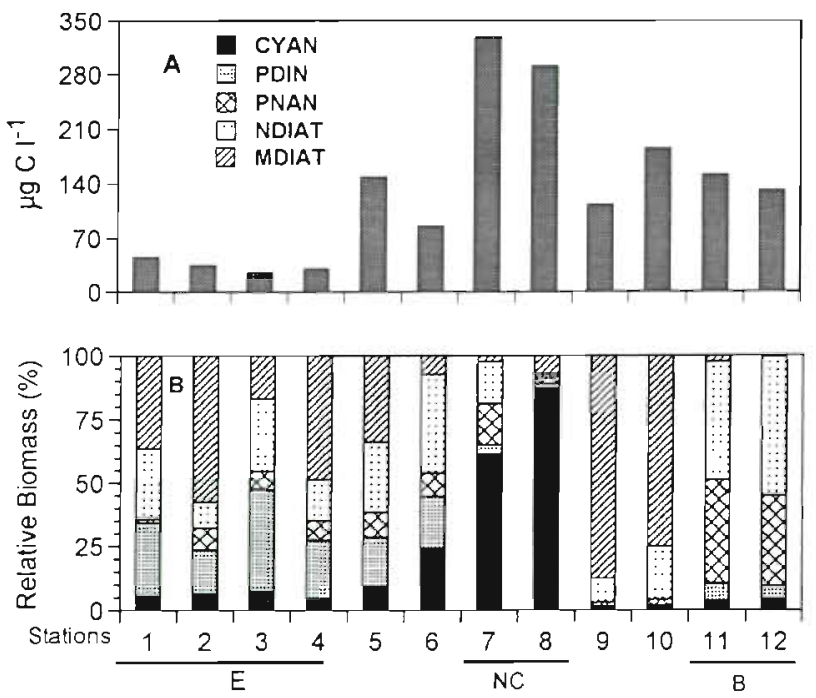

Fig. 3. (A) Phytoplankton biomass and (B) proportional rontributions of different size and taxonomic groups. Abbresiations as in Fig. 2. Regions and stations as in Fig. 1 

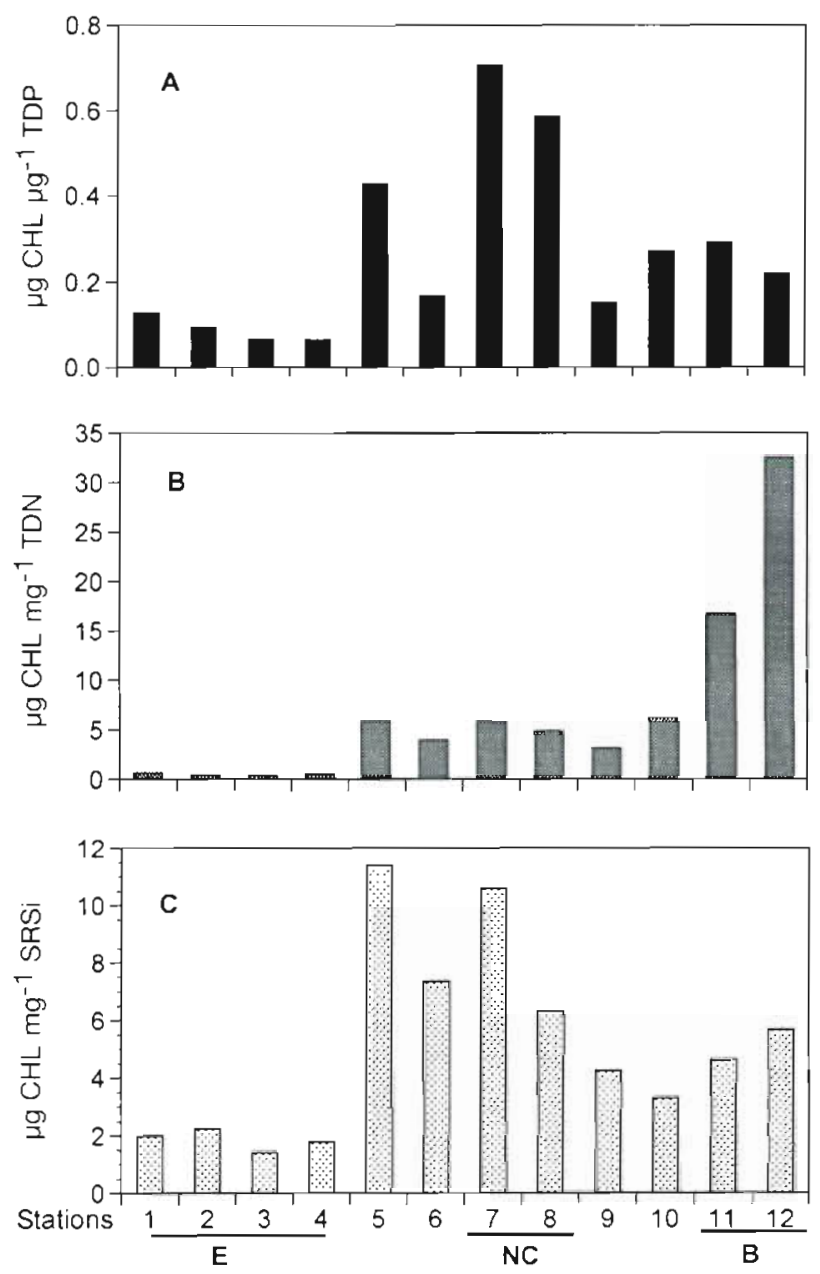

Fig. 4. Ratios of chlorophyll (CHL) to dissolved nutrients: (A) total dissolved phosphorus; TDP; (B) total dissolved nitrogen, TDN; and (C) soluble reactive silicon, SRSi. Regions and stations as in Fig. 1

nanoflagellates (PNAN), chiefly chlorophytes, and centric nanodiatoms at Samphire Key.

In the boundary region, the nanodiatoms Navicula, Nitzschia, and Cyclotella were responsible for the bulk of phytoplankton biomass together with PNAN, mainly cryptomonads and chrysophytes. The predominance of nanophytoplankton corresponded to the elevated CHL:TDN and low PHYT:CHL ratios. The diverse assemblage of large and chain-forming diatoms found here, including Asterionelopsis, Chaetoceros, Skeletonema and Thalassiosira, contributed insignificantly to phytoplankton biomass as compared to nanodiatoms and PNAN.

At Rabbit Key, the large diatom Rhizosolenia formed ca $90 \%$ of phytoplankton biomass. This taxon codominated with Proboscia and Fragillaria at Murray Key. At Peterson Key, phytoplankton biomass consisted of Synechococcus (24\%) and the nanoplanktonic
Peridinium and Gymnodinium, and PNAN, whereas Cotton Key Basin had a larger proportion of microdiatoms and a negligible proportion of cyanobacteria. The latter 2 sites had higher chlorophyll concentrations and chlorophyll:nutrient ratios than the adjacent eastern locations.

For all sites, chlorophyll concentrations were correlated with TDP, $\mathrm{NH}_{4}{ }^{+}$, and SRSi $(\mathrm{r}=0.66,0.83$, and 0.78 , respectively) as well as with $\mathrm{PC}, \mathrm{PN}$, and $\mathrm{PP}(\mathrm{r}=0.88$, $0.88,0.90$, respectively). The CHL:TDP ratios were correlated with $\mathrm{NH}_{4}{ }^{+}(\mathrm{r}=0.80)$ and SRSi $(\mathrm{r}=0.67)$ whereas the CHL:SRSi ratio was correlated with $\mathrm{NO}_{3}{ }^{-}$ $(r=0.67)$. The CHL:TDN ratio was correlated with TDP $(r=0.60)$. The PHYT:CHL ratio increased with the increasing proportion of large-sized taxa in phytoplankton biomass $(\mathrm{r}=0.80)$ and was negatively related to TDP $(r=-0.85)$ and SRSi $(r=-0.63)$. The MRUBR: PHYT ratio exhibited a positive correlation with the TDN:TDP ratio $(0.77)$ and negative correlations with TDP $(r=-0.84)$ and SRSi $(r=-0.61)$.

\section{Microbial food web}

The eastern region had the highest bacterial biomass to chlorophyll ratio (BAC:CHL) and an elevated proportion of large $(>1 \mu \mathrm{m})$ bacterial cells (Table 3 ). The overall protozoan population was low with insignificant abundances of heterotrophic nanoflagellates (HNAN) and an elevated proportion of heterotrophic dinoflagellates (HDIN). Pastidic oligotrichs, specifically Laboea and Strombidium, were predominant in
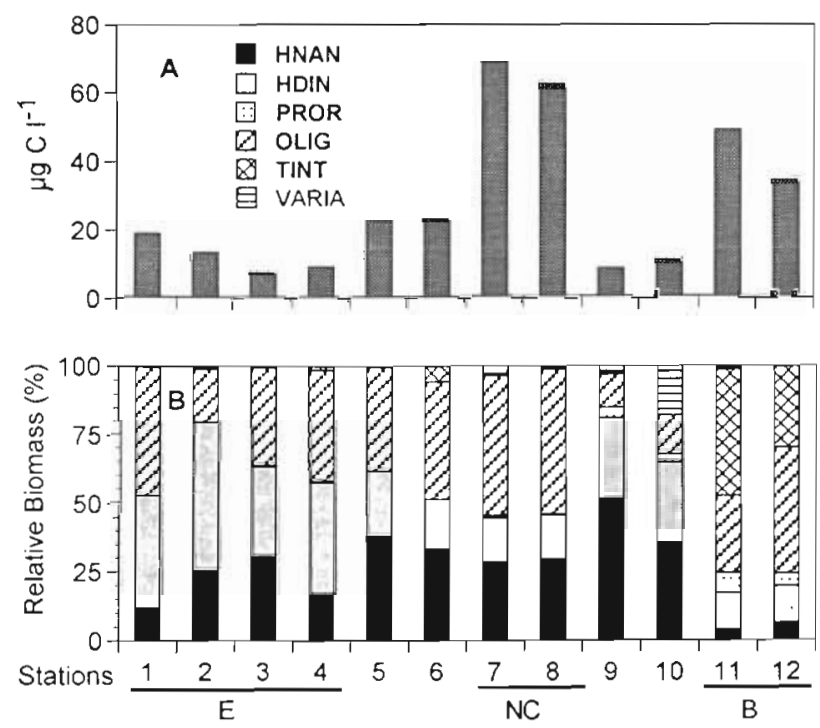

Fig. 5. (A) Protozoan biomass and (B) proportional contributions of different size and taxonomic groups. Abbreviations as in Fig. 2. VARIA: other protozoa. Regions and stations as in Fig. 1 
the ciliate assemblage. The ratio between protozoan biomass (excluding Mesodinium rubrum) and phytoplankton biomass (PROT:PHYT) peaked at Duck Key followed closely by Buttonwood Sound.

The highest absolute concentrations of viruses, bacteria, and protozoa occurred in the north-central region. Protozoan biomass was primarily formed by oligotrichs and HNAN, followed by HDIN. Aplastidic chysophytes and bodoniids and Gymnodinium were the predominant forms of HNAN and HDIN, respectively. The nanoplankton-sized Lohmaniella and Strobilidium were the most numerous in the ciliate assemblage, whereas larger Strobilidium, Strombidinopsis, and the hypotrich Euplotes contributed to its biomass.

The boundary region had low bacterial biomass and BAC:CHL ratios. The PROT:PHYT ratios were close to those in the eastern bay. The contribution of HNAN was low in this region with an otherwise abundant protozoan community formed by the microzooplanktonsized tintinnids Tintinnopsis, Stenostomella and Metacyclis and the small oligotrichs Strobilidium and Lohmaniella. The abundance of the small prorodontid ciliate Urotricha also peaked at the Gulf border. Peterson Key was the only other location where the proportional contribution of tintinnids was higher than $1 \%$.

Rabbit and Murray Keys were characterized by the lowest protozoan biomass and PROT:PHYT ratio of any of the regions. The protozooplankton had elevated proportions of HDIN and HNAN and of the mixotrophic haptorid ciliate Askenasia but a very low proportion of oligotrichs and no tintinnids. Choanoflagellates, the dinoflagellates Dynophisis and Noctiluca, and peritrich ciliates, as well as the prorodontid ciliate Tiarina, occurred at these and other sites but were not quantitatively important.

For all sites, the abundance of viruses was significantly correlated with biomass of cyanobacteria ( $\mathrm{r}=$ 0.98 ) and bacteria $(r=0.81)$. Bacterial biomass was, in turn, correlated with cyanobacteria $(r=0.90)$ and $P C$ $(r=0.76)$. The total biomass of protozoa was related to chlorophyll $(\mathrm{r}=0.89)$, whereas the biomass of oligotrichs, HDIN, and HNAN were correlated with that of cyanobacteria ( $\mathrm{r}=0.92,0.83$, and 0.95 , respectively) and bacteria ( $r=0.78,0.76$ and 0.91 , respectively). The biomass of tintinnids and prorodontids were correlated with that of PNAN ( $\mathrm{r}=0.75$ and 0.66 ) and nanodiatoms $(\mathrm{r}=0.69$ and 0.75 , respectively).

The PROT:PHYT ratio was negatively correlated with the relative biomass of HNAN $(r=-0.70)$ and positively with the MRUBR:PHYT $(r=0.63)$ and BAC:CHL $(r=0.56)$ ratios. The latter ratio decreased with the increasing HNAN:BAC ratio ( $\mathrm{r}=-0.71)$. The proportion of large bacterial cells $(>1 \mu \mathrm{m})$ in BAC biomass was negatively correlated with the HNAN:BAC ratio $(r=0.60)$.

\section{DISCUSSION}

The prevalence of particulate $\mathrm{P}$ over dissolved $\mathrm{P}$ concentrations and the strong correlation between CHL and particulate $P$ indicate that a large proportion of $P$ in the water column was plankton-bound and are consistent with $P$ being the major limiting nutrient in Florida Bay. Elemental ratios in rhodophytes (LaPointe 1989) and seagrass (Fourqurean et al. 1992) tissues, as well as in seston (Fourqurean et al. 1993), have previously demonstrated $\mathrm{P}$ limitation in Florida Bay. The high $\mathrm{P}$ absorbency of the calcareous environment of the Everglades and the prevalence of calcareous sediments (Fourequrean et al. 1993) are thought to contribute to the deficiency of this nutrient in Florida Bay. In addition, P may be selectively removed by the coastal fringe of mangroves (Reyes et al. 1995). However, as shown in the following paragraphs, we conclude that multiple resource limitation in combination with biotic interactions rather than $P$ limitation alone were responsible for the observed patterns of the microbial plankton.

\section{Eastern region}

Both the concentration of SRP and seston elemental stoichiometry suggest severe $P$ limitation in the eastern region (Healey \& Hendzel 1980, Hecky et al. 1993). At the same time, the low CHL:TDP ratios and low SRSi concentrations suggest that the availability of the latter nutrient may have additionally limited the growth of diatom phytoplankton in this part of Florida Bay. This assumption is also supported by bioassay tests showing the co-limiting role of $\mathrm{Si}$ in Florida Bay (Tomas \& Bendis 1995).

The community structure and seston stoichiometry in eastern Florida Bay appears to reflect strong competition for the limiting resources and diverse survival strategies in microbial plankton. Based on the composition of phytoplankton and the negative relationships found between the PHYT:CHL ratio and the concentrations of TDP and SRSi, we may expect low growth rates and $K$-selection (i.e. selection under carrying capacity conditions and high level of competition) for large-sized phytoplankton adapted to nutrient deficiency of the eastern region. Although the above ratio is affected by different pigment makeup of various taxonomic groups, it may provide information about the effects of resources on algal physiology (Cloern et al. 1995, Taylor et al. 1997). The occurrence of potentially toxic algae, such as Gambrierdiscus, in the eastern region is also consistent with their $K$-selection (Kilham \& Hecky 1988).

In Florida Bay, the bacterial size fraction $(<0.8 \mu \mathrm{m})$ accounts for a large proportion of the total ${ }^{33} \mathrm{PO}_{4}$ up- 
take (J. Cotner, University of Minnesota, pers. comm.) and consequently phytoplankton may undergo strong competition for $\mathrm{P}$ with bacteria. Unbalanced nutritional conditions of phytoplankton in the eastern region, as indicated by high particulate C:P and N:P ratios, may have stimulated algal dissolved organic carbon (DOC) release that would, in turn, fuel bacteria (Bratback \& Thingstad 1985). The high BAC:CHL ratio observed in this region provides evidence for the above hypothesis. Bacteria, which have high affinities and requirements for phosphate (Cotner \& Wetzel 1992, Bjorkman \& Karl 1994), can take up and store $P$ in excess of their growth requirements (Kulaev \& Vagabov 1983) and release $N$ at $\mathrm{N}: \mathrm{P}>20$ (Elser et al. 1995), thus exacerbating the nutrient misbalance. The supposition that bacteria decrease $P$ availability relative to $N$ availability is further supported by ${ }^{15} \mathrm{NH}_{4}{ }^{+}$-isotope dilution experiments in Florida Bay, where $\mathrm{N}$ cycling rates were enhanced after simultaneous addition of $\mathrm{PO}_{4}$ and dissolved free amino acids (DFAA) as compared to additions of DFAA without P (Gardner \& Cavaletto unpubl. data).

In the eastern region, where phytoplankton biomass was dominated by large-sized taxa, herbivorous microzooplankton may have exerted additional predation pressure on HNAN, thus diminishing the effects of bacterivory. These speculations are supported by the significant correlations between the corresponding microbial parameters (i.e. the HNAN: $\mathrm{BAC}$ ratio vs the $\mathrm{BAC}: \mathrm{CHL}$ ratio and the PROT:PHYT ratio vs the proportional biomass of HNAN). Furthermore, a negative correlation between the proportional biomass of large bacterial cells and the HNAN:BAC ratio may reflect cascading trophic effects on bacteria (Jürgens \& Güde 1994, Lavrentyev et al. 1997).

Several taxa forming a large proportion of microbial plankton biomass in the eastern region are known to be mixotrophic. Mixotrophy, i.e. the ability to switch between phagotrophic and autotrophic modes of nutrition, is an important adaptation to resource limitation (Raven 1997). Specifically, many photosynthetic dinoflagellates can feed on other algae (Strom \& Strom 1996, Stoecker et al. 1997), whereas mixotrophic oligotrichs use photosynthetic products of functional chloroplasts to supplement their diet (Stoecker \& Silver 1990). The ultimate symbiotrophic organism, Mesodinium rubrum, which peaked in the eastern region, derives nutrition exclusively from the photosynthetic products of endosymbionts that, in turn, use its metabolic products as the only source of N and P (Stoecker et al. 1991). Depletion of nutrients and stable warm weather have preceded its boom in San Francisco Bay, USA (Cloern et al. 1994).

\section{North-central region}

The Synechococcus bloom in the north-central region illustrates the previously noted complications of the predictive power of elemental ratio analyses (Paerl 1988). Although the seston stoichiometry and turbidity level indicated strong $\mathrm{P}$ and light limitation, respectively, in this region, the bloom coincided with relatively low PHYT:CHL ratios and high concentrations of all particulate nutrients and heterotrophic plankton

The relatively deep layer of muddy sediments, especially in the north-central region, and the shallow and polymictic character of Florida Bay are conducive to significant resuspension of sediments (Phlips et al. 1995). However, the tight correlations between seston concentrations and chlorophyll and microbial biomass point out the largely pelagic origin of the suspended material collected at these and other studied sites. Relatively low wind conditions on the sampling date, the insignificant variability of the PC:PN ratio, and small proportions of typically benthic forms of diatoms and protozoa in the microbial plankton samples reduce concerns about potential bias from wind-induced resuspension of sediment particles.

Salinity-induced physiological stress in Thalassia and the resultant decomposition of the seagrass beds are reasonably thought to have provided a nutrient source for the proliferation of cyanobacteria (Boesch et al. 1993). On the other hand, we found the highest concentrations of $\mathrm{NH}_{4}{ }^{+}$and Synechococcus in the areas which may have been influenced by Taylor Slough, the major source of freshwater in the bay. These results appear to be consistent with the notion that the bloom was stimulated by run-off into the bay (LaPointe \& Clark 1992). A survey outside the main key line also has shown poor water quality near marinas and canals with elevated concentrations of $\mathrm{N}$ and chlorophyll (Szmant \& Forrester 1996). None of the above observations, however, appears to explain why the bloom has persisted for several years over the completely denuded sediments in Rankin Key Basin, or through the dry season.

Synechococcus blooms are not unique to Florida Bay. In the lagoons of Camacchino (Italy), which are characterized by low water exchange and strong anthropogenic impacts, a mega-bloom (>300 mg wet weight $\mathrm{l}^{-1}$ ) of this cyanobacterium resulted in depletion of metazooplankton, production of $\mathrm{H}_{2} \mathrm{~S}$ in sediments, seagrass die-offs, and the collapse of mullet and eel fisheries (Sorokin et al. 1996). The bloom persisted despite SRP concentrations $<0.1 \mu \mathrm{M}$.

The picoplanktonic chroococcoid Synechococcus is a superior competitor for phosphate, combining high affinity for this nutrient with high uptake velocities and the ability for luxury uptake, and has remarkable 
adaptations to adverse environmental conditions (Stockner 1988). Specifically, it has a broad tolerance to salinity (Phlips et al. 1989) and can saturate photosynthesis and growth at very low irradiances (Stockner 1988). In addition, Synechococcus can assimilate various dissolved organic compounds (Luo \& Mitsui 1994), which means it may be able to use P from the organic pool (Sorokin et al. 1996).

The ability of Synechococcus to fix N (Phlips et al. 1989) was not likely an important factor in the $N$-rich north-central region, since this energetically costly process is likely inhibited in the presence of elevated $\mathrm{NH}_{4}{ }^{+}$. However, it further illustrates the extraordinary physiological plasticity of this taxon. High concentrations of dissolved $\mathrm{N}$ in the north-central region may have influenced the bloom, since the availability of $N$ to P-starved plankton allows relatively high synthesis of chlorophyll and protein as compared to P-starved plankton without excess $N$ (Berdalet et al. 1996). The prevalence of $\mathrm{NH}_{4}{ }^{+}$over nitrates may have been beneficial to cyanobacteria, such as Synechococcus, which have a clear preference for the former nutrient (Stockner 1988) and use it more efficiently than most eukaryotes due to the difference in enzymes (Blomqvist et al. 1994).

The concentrations of viruses in the north-central region were much higher than those found in the rest of Florida Bay in this and a previous study (Paul et al. 1993). This factor may also have contributed to the predomination of Synechococcus over other phytoplankton in this region. The cyanobacterium is more resistant to viral infection than other algae and bacteria (Waterbury \& Valios 1993, Suttle 1994), even though the abundance of viruses often tracks its abundance (Suttle \& Chan 1994). At the same time, diatom phytoplankton, already suffering from $\mathrm{P}$ limitation and Synechococcus-induced light limitation, were likely vulnerable to viral lysis.

We speculate that nutrient recycling was an important source of $P$ for cyanobacteria in the north-central region, based on the following premises. (1) The abundance and structure of the microbial community, which was heavily dominated by HNAN and small filterfeeding ciliates, were conducive to active grazing, since both Synechococcus and bacteria are desirable food organisms for these protozoa (Sherr et al. 1989, Fahnenstiel et al. 1991). (2) The protozoan assemblage at these sites also included relatively large, potentially predacious protists (e.g. Euplotes and Gymnodinium). This fact corresponds well to the lack of increase in PC in a bioassay test conducted at the Rankin Key site at the time of this survey (Bootsma unpubl.), because much of the acquired carbon would be respired in this multi-step trophic cascade (Legendre \& Rassoulzadegan 1995). At the same time, nutrient recycling must have been highly efficient in such a system (Suzuki et al. 1996). (3) Isotope dilution experiments using ${ }^{15} \mathrm{NH}_{4}{ }^{+}$ showed that pelagic processes were responsible for the bulk of recycled $\mathrm{NH}_{4}{ }^{+}$at Rankin Key, whereas benthic processes were more important at Duck, Murray, and Rabbit Keys (Gardner unpubl, data).

\section{Boundary region}

In contrast to the 2 inner regions described above, the shelf-influenced waters of Spigger and Oxfoot Banks had nutrient conditions and microbial plankton more typical for marine systems. Particulate N:P ratios and CHL:TDP and CHL:TDN ratios indicated the increasing $\mathrm{N}$ deficiency at the Gulf border, whereas $\mathrm{P}$ limitation showed the opposite trend. Characteristically, the diatom Skeletonema, which is very sensitive to $\mathrm{P}$ deficiency due to its high ATP (adenosine triphosphate) content (Haigh et al. 1992 and references therein), occurred only at Oxfoot Bank.

The HET:PHOT ratios were high at the Gulf border, where tintinnids and other microzooplankton formed tight trophic links to the predominant nanophytoplankton, as suggested by the statistical relationships. In this case, the above ratio may have reflected the efficiency of carbon transfer between producers and consumers in the pelagic zone (Verity et al. 1996). Nutrient ratios approaching the Redfield equilibrium at the Gulf border agree with the notion that the secondary productivity is higher in $\mathrm{N}$-deficient than in $\mathrm{P}$-deficient systems given the same rate of $\mathrm{C}$ fixation (Hecky et al. 1993). The low concentrations of bacteria and $\mathrm{BAC}: \mathrm{CHL}$ ratios in the western region may be a result of low DOC release during balanced phytoplankton growth. Plastidic nanoflagellates (PNAN), abundant at these sites, may have also contributed to low bacterial biomass by grazing bacteria to obtain necessary nutrients (e.g. Arenowski et al. 1995).

\section{Other (transitional) sites}

The characteristics of 4 sites differed from those of the 3 regions described above. This result is not surprising, given the heterogeneity of abiotic conditions in Florida Bay. In fact, all of these sites were considered to be in different eco-regions in an earlier study of Florida Bay (Phlips \& Badylak 1996). The composition of microbial community and nutrient conditions suggest that Peterson Key may have been simultaneously influenced by waters from the north-central region and Florida Straits, and Cotton Key Basin by the latter marine waters and the eastern region. Murray Key appeared to be transitional between the Gulf- 
influenced western edge of Florida Bay and the nutrient poor seagrass-dominated areas in the south-central section represented here by Rabbit Key.

\section{CONCLUSIONS}

The above 'snap-shot' of resource conditions and plankton distributions strongly resembles the picture portrayed in more temporally extensive studies in Florida Bay (Fourqurean et al. 1993, Phlips \& Badylak 1996). Thus, the results of this $1 \mathrm{~d}$ survey appear to reflect some general patterns in the Florida Bay ecosystem. Although we realize that physical factors may have influenced the distribution of planktonic organisms, the consistency between our results and previously described spatial patterns suggest that multiple resource gradients are the predominant factor determining the structure of planktonic communities in the partially isolated regions of Florida Bay. This conclusion is also supported by the significant relationships between the concentrations of nutrients and biological parameters.

The emerging picture of resource limitation in Florida Bay suggests that resource-driven microbial food web processes may have feedback effects on trophic conditions in this coastal lagoon. For example, the unique physiological adaptations of Synechococcus and nutrient recycling by the microbial loop appear to have ensured nutrient sufficiency for extensive periods, despite the apparent $\mathrm{P}$ deficiency in Florida Bay. Combined with diverse survival strategies in the microbial plankton and the selective nature of $\mathrm{Si}$ limitation, it is clear that a better understanding of the ecological situation in Florida Bay requires a balanced holistic approach emphasizing the interplay of different abiotic resources and biotic interactions, including those involving crustacean zooplankton (e.g. Miller et al. 1995).

Acknowledgements. This research was sponsored by NOAA's Coastal Ocean Progam. The Nancy Lee and Perry Bass Endowed Chair funding to the University of Texas Marine Science Institute supported manuscript preparation. We thank James Cotner and Rosie Sada for help in sample collection and for sharing unpublished data on bacterial P-uptake, the staff of Keys Marine Laboratory for laboratory and field support, Lee Fuiman for suggestions on statistics, and James Cotner, Greta Fryxell, and 3 anonymous reviewers for critical evaluation of this work. This is GLERL contribution 1064 and UTMSI contribution 1057.

\section{LITERATURE CITED}

Arenowski AL, Lim EL, Caron DA (1995) Mixotrophic plankton in oligotrophic surface waters of the Sargasso Sea may employ phagotrophy to obtain major nutrients. J Plankton Res 17:801-820
Berdalet E, Marrase C, Estrada M, Arin L, MacLean ML (1996) Microbial community response to nitrogen- and phosphorus-deficient nutrient inputs: microplankton dynamics and biochemical characterization. J Plankton Res 18:1627-1641

Bjorkman K, Karl DM (1994) Bioavailability of inorganic and organic phosphorus compounds to natural assemblages of microorganisms in Hawaiian coastal waters. Mar Ecol Prog Ser 111:265-273

Blomqvist P, Peterson A, Hyenstrand P (1994) Ammoniumnitrogen: a key regulatory factor causing dominance of non-nitrogen-fixing cyanobacteria in aquatic systems. Arch Hydrobiol 132:141-164

Boesch DF, Armstrong NE, D'Elia CF, Maynard NG, Paerl HN, Williams SL (1993) Deterioration of the Florida Bay ecosystem: an evaluation of the scientific evidence. Report to the Interagency Working Group on Florida Bay. Department of the Interior, National Park Service, Washington, DC

Bratbak G. Thingstad TF (1985) Phytoplankton-bacteria interactions: an apparent paradox? Analysis of a model system with both competition and commensalism. Mar Ecol Prog Ser 25:23-30

Butler MJ IV, Hunt JH, Herrnkind WF, Childress MJ Bertelsen R, Sharp W, Matthews T, Field JM, Marshall HG (1994) Cascading disturbances in Florida Bay, USA cyanobacteria bloom, sponge mortality, and implications for juvenile spiny lobsters Panulirus argus. Mar Ecol Prog Ser 129:119-125

Caron DA, Dam HG, Kremer P, Lessard EJ, Madin LP, Malone TC, Napp JM, Peele ER, Roman MR, Youngbluth MJ (1995) The contribution of microorganisms to particulate carbon and nitrogen in surface waters of the Sargasso Sea near Bermuda. Deep Sea Res (Part I) 42:943-972

Cloern JE, Cole BE, Hager SW (1994) Notes on a Mesodinium rubrum red tide in San Francisco Bay (California, USA). J Plankton Res 16:1269-1276

Cloern JE, Grenz C, Vidergar-Lucas L (1995) An empirical model of the phytoplankton chlorophyll:carbon ratio - the conversion factor between productivity and growth rate. Limnol Oceanogr 40:1313-1321

Cotner JB Jr, Wetzel RG (1992) Uptake of dissolved inorganic and organic phosphorus compounds by phytoplankton and bacterioplankton. Limnol Oceanogr 37:232-243

Davis CO, Simmons MS (1979) Water chemistry and phytoplankton field and laboratory procedures. Report no. 70. Great Lakes Research Division, Univ Michigan, Ann Arbor

Elser JJ, Chrzanowski TH, Sterner RW, Schampel JH, Foster DK (1995) Elemental ratios and the uptake of nutrients by phytoplankton and bacteria in three lakes of the Canadian Shield. Microb Ecol 29:145-162

Elser JJ, Hasset PR (1994) A stoichiometric analysis of the zooplankton-phytoplankton interactions in marine and freshwater ecosystems. Nature 370:211-213

Fahnenstiel GL, Carrick HJ, Ituraga R (1991) Physiological characteristics and food web dynamics of Synechococcus in Lakes Huron and Michigan. Limnol Oceanogr 36:219-234

Fahnenstiel GL, McCormick MJ, Lang GA, Redalje DG Lohrenz SE, Markowitz M, Wagoner B, Carrick HJ (1995) Taxon-specific growth and loss rates for dominant phytoplankton populations from the northern Gulf of Mexico. Mar Ecol Prog Ser 117:229-239

Fourqurean JW, Jones RD, Zieman JC (1993) Processes influencing water column nutrient characteristics and phosphorus limitation of phytoplankton biomass in Florida Bay, $F L$, USA: inferences from spatial distributions. Estuar Coast Shelf Sci 36:295-314 
Fourqurean JW, Zieman JC, Powell GVN (1992) Phosphorus limitation of primary production in Florida Bay: evidence from C:N:P ratios of the dominant seagrass Thalassia testudinum. Limnol Oceanogr 37:162 -171

Gardner WS, St John PA (1991) High-performance liquid chromatographic method to determine ammonium ion and primary amines in seawater. Anal Chem 63:537-540

Goldman JC, Glibert PM (1983) Kinetics of nitrogen uptake by phytoplankton. In: Carpenter EJ, Capone DG (eds) Nitrogen in the marine environment. Academic Press, New York, p 233-274

Haigh R, Taylor FJR (1991) Mosaicism of microplankton communities in the northern Straits of Georgia, British Columbia. Mar Biol 110:301-314

Haigh R, Taylor FJR, Sutherland TF (1992) Phytoplankton ecology of Sechelt Inlet, a fjord of the British Columbia coast. I. General features of the nano- and microplankton. Mar Ecol Prog Ser 89:117-134

Healey FP, Hendzel LL (1980) Physiological indicators of nutrient deficiency in lake phytoplankton. Can J Fish Aquat Sci 37:442-453

Hecky RE, Campbell P, Hendzel LL (1993) The stoichiometry of carbon, nitrogen, and phosphorus in particulate matter of lakes and oceans. Limnol Oceanogr 38:709-724

Hecky RE, Kilham P (1988) Nutrient limitation of phytoplankton in freshwater and marine environments: a review of recent evidence on the effects of enrichment. Limnol Oceanogr 33:796-822

Hennes KP, Suttle CA (1994) Direct counts of viruses in natural. waters and laboratory cultures by epifluorescence microscopy. Limnol Oceanogr 40:1050-1055

Jürgens K, Güde $H$ (1994) The potential importance of grazing-resistant bacteria in planktonic systems: a review. Mar_Ecol Prog Ser 112:169-188

Kilham $\bar{P}$, Hecky RE (1988) Comparative ecology of marine and freshwater phytoplankton. Limnol Oceanogr 33:776-795

Kulaev IS, Vagabov VM (1983) Polyphosphate metabolism in microorganisms. Adv Microb Physiol 24:83-171.

LaPointe BE (1989) Macroalgal production and nutrient relations in oligotrophic areas of Florida Bay. Bull Mar Sci $44: 312-323$

LaPointe BE, Clark MW (1992) Nutrient inputs from the watershed and coastal eutrophication in the Florida Keys. Estuaries 15:465-476

Lavrentyev PJ, Gardner WS, Johnson JR (1997) Cascading trophic effects on aquatic nitrification: experimental evidence and potential implications. Aquat Microb Ecol 13: $161-175$

Legendre L, Rassoulzadegan F (1995) Plankton and nutrient dynamics in marine waters. Ophelia 41:153-172

Luo YH, Mitsui A (1994) Hydrogen production from organic substrates in an aerobic nitrogen-fixing marine unicellurar cyanobacterium Synechococcus sp. strain Miami BG 043511. Biotech Bioeng 44:1255-1260

Menzel DW, Corwin N (1965) The measurement of total phosphorus seawater based on the liberation of organically bound fractions by persulfate oxidation. Limnol Oceanogr 10:280-281

Miller CA, Penry DL, Glibert PM (1995) The impact of trophic interactions on rates of nitrogen regeneration and grazing in Chesapeake Bay. Limnol Oceanogr 40:1005-1011

Montagnes DJS (1995) Growth response of planktonic ciliates in the genera Strobilidium and Strombidium. Mar Ecol Prog Ser 130:241-254

Montagnes DJS. Berges JA, Harrison PJ, Taylor FJR (1994) Estimating carbon, protein, and chlorophyll a from volume in marine phytoplankton. Limnol Oceanogr 39:1044-1060
Montagnes DJS, Lynn DH (1987) A quantitative Protargol stain (QPS) for ciliates: method description and test of its quantitative nature. Mar Microb Food Webs 2:83-93

Montague CL, Ley JA (1993) A possible effect of salinity fluctuation on abundance of benthic vegetation and associated fauna in northeastern Florida Bay. Estuaries 16: 703-717

Nielsen TG, Kiørboe T (1991) Effects of a storm event on the structure of the pelagic food web with special emphasis on planktonic ciliates. J Plankton Res 13:35-51

Norland S (1993) The relationship between biomass and volume of bacteria. In: Kemp PF, Sherr BF, Sherr EB, Cole JJ (eds) Handbook of methods in aquatic microbial ecology. Lewis, Boca Raton, p 303-307

Paerl HW (1988) Nuisance phytoplankton blooms in coastal, estuarine, and inland waters. Limnol Oceanogr 33:823-847

Paul JH, Rose JB, Jiang SC, Kellog CA, Dickson L (1993) Distribution of viral abundance in the reef environment of Key Largo, Florida. Appl Environ Microbiol 59:718-724

Phlips EJ, Badylak S (1996) Spatial variability in phytoplankton standing crop and composition in a shallow inner-shelf lagoon, Florida Bay, Florida. Bull Mar Sci 58:203-216

Phlips EJ, Lynch TC, Badylak S (1995) Chlorophyll a, tripton, color, and light availability in a shallow tropical inner-shelf lagoon, Florida Bay, USA. Mar Ecol Prog Ser 127:223-234

Phlips EJ, Zeman C, Hansen P (1989) Growth, photosynthesis, nitrogen fixation and carbohydrate production by a unicellular cyanobacterium, Synechococcus sp. (Cyanophyta). J Appl Phycol 1:137-145

Porter KG, Feig YC (1980) The use of DAPI for identifying and counting aquatic microflora. Limnol Oceanogr 25:943-948

Putt M, Stoecker DK (1989) An experimentally determined carbon:volume ratio for marine oligotrichous ciliates from estuarine and coastal waters. Limnol Oceanogr 34:177-183

Raven JA (1997) Phagotrophy in phototrophs. Limnol Oceanogr 42:198-205

Reyes E, Day JW Jr, Perez BC, Childers DL (1995) Nutrient exchange between Florida Bay and the Everglades salinity transition zone. Florida Bay Science Conference, Gainesville, Florida, October 1995, p 20-22

Sherr BF, Sherr EB, Hopkinson CS (1988) Trophic interactions within pelagic microbial communities: indications of feedback regulation of carbon flow. Hydrobiologia 159:19-26

Sherr EB, Caron DA, Sherr BF (1993) Staining of heterotrophic protists for visualization via epifluorescence microscopy. In: Kemp PF, Sherr BF, Sherr EB, Cole JJ (eds) Handbook of methods in aquatic microbial ecology. Lewis, Boca Raton, p 213-228

Sherr EB, Rassoulzadegan F, Sherr BF (1989) Bacterivory by pelagic choreotrichous ciliates in coastal waters of the NW Mediterranean sea. Mar Ecol Prog Ser 55:235-240

Skibbe O (1994) An improved quantitative protargol stain for ciliates and other planktonic protists. Arch Hydrobiol 132: $257-278$

Sommer U (1993) Phytoplankton competition in Plußsee: a filed test of the resource-ratio hypothesis. Limnol Oceanogr 38:838-845

Sorokin YuI, Sorokin PYu, Gnes A. (1996) Structure and functioning of the anthropogenically transformed Comacchino lagoonal ecosystem (Ferrara, Italy). Mar Ecol Prog Ser 133: $57-71$

Stockner JG (1988) Phototrophic picoplankton: an overview from marine and freshwater ecosystems. Limnol Oceanogr 33:765-775

Stoecker DK, Li A, Coats DW, Gustafson DE, Nannen MK (1997) Mixotrophy in the dinoflagellate Prorocentrum minimum. Mar Ecol Prog Ser 152:1-12 
Stoecker DK, Putt M, Davis LH, Michaels AE (1991) Photosyntheis in Mesodinium rubrum: species-specific measurements and comparison to communiy rates. Mar Ecol Prog Ser 73:245-252

Stoecker DK, Silver MW (1990) Replacement and aging of chloroplasts in Strombidium capitatum (Ciliophora: Oligotrichida). Mar Biol 107:491-502

Strickland JDH, Parsons TR (1972) A practical handbook for seawater analysis, 2nd edn. Bull Fish Res Bd Can 167

Strom SL, Strom MW (1996) Microplankton growth, grazing, and community structure in the northern Gulf of Mexico. Mar Ecol Prog Ser 130:229-240

Suttle CA (1994) The significance of viruses to mortality in aquatic microbial communities. Microb Ecol 28:237-244

Suttle CA, Chan AM (1994) Dynamics and distribution of cyanophages and their effects on marine Synechococcus spp. Appl Environ Microbiol 60:3167-3174

Suzuki M, Sherr EB, Sherr BF (1996) Estimation of ammonium regeneration efficiencies associated with bacterivory in pelagic food webs via a ${ }^{15} \mathrm{~N}$ tracer method. J Plankton Res 18:411-428

SYSTAT for Windows: Statistics (1992) SYSTAT, Inc, Evanston

Editorial responsibility: Evelyn and Barry Sherr

(Contributing Editors), Corvallis, Oregon, USA
Szmant AM, Forrester A (1996) Water column and sediment nitrogen and phosphorus distribution patterns in the Florida Keys, USA. Coral Reefs 15:21-24

Taylor AH, Geider RJ, Gilbert FJH (1997) Seasonal and latitudinal dependencies of phytoplankton carbon-to-chlorophyll a ratios: results of a modeling study. Mar Ecol Prog Ser 152:51-66

Thayer GW, Murphey PL, Lacroix MW (1994) Responses of plant communities in western Florida Bay to the die-off of seagrasses. Bull Mar Sci 54:718-726

Tomas CR, Bendis B (1995) Phytoplankton dynamics studies in Florida Bay. Florida Bay Science Conference. Gainesville, Florida, October 1995, p 155-157

Verity PG, Paffenhofer GA, Wallace D, Sherr EB, Sherr BF (1996) Composition and biomass of plankton in spring on the Cape Hatteras shelf, with implications for carbon flux. Cont Shelf Res 16:1087-1116

Wang JD, van de Kreeke J, Krishnan N, DeWitt S (1994) Wind and tide response in Florida Bay. Bull Mar Sci 54:579-601

Waterbury JB, Valios FW (1993) Resistance to co-occurring phages enables marine Synechococcus coomunities to coexist with cyanophages abundant in seawater. Appl Environ Microbiol 59:3393-3399

Submitted: June 27, 1997; Accepted: January 14, 1998 Proofs received from author(s): April 2, 1998 